Journal of Southeast Asian

\title{
Selected Poems: Folklore \& legend: Kaundinya \& Soma; The Mekong to Mundus Novus; The Tonle Sap; Touching Water; Water the Goddess
}

Peuladd Huy

Follow this and additional works at: https://docs.lib.purdue.edu/jsaaea

\section{Recommended Citation}

Huy, Peuladd (2014) "Selected Poems: Folklore \& legend: Kaundinya \& Soma; The Mekong to Mundus Novus; The Tonle Sap; Touching Water; Water the Goddess," Journal of Southeast Asian American Education and Advancement. Vol. 9 : Iss. 1, Article 4.

DOI: $10.7771 / 2153-8999.1079$

Available at: https://docs.lib.purdue.edu/jsaaea/vol9/iss1/4

This document has been made available through Purdue e-Pubs, a service of the Purdue University Libraries. Please contact epubs@purdue.edu for additional information.

This is an Open Access journal. This means that it uses a funding model that does not charge readers or their institutions for access. Readers may freely read, download, copy, distribute, print, search, or link to the full texts of articles. This journal is covered under the CC BY-NC-ND license. 


\section{JSA AEA

Volume 9 (2014)

\title{
Selected Poems
}

\author{
by \\ Peauladd Huy
}

\section{Folklore \& legend: Kaundinya \& Soma}

When sacred wandered into the serpent's nest

a race emerged \& a nation forged - a lifetime's bound by nectar

$\&$ poison in increments - amongst the half-blood

offspring: the half upright \& half slither

inching from Khorat highlands to the lowlands of the Mekong.

No sooner than step did shadow

burn white as a midday

glinted sabers and mercenary paths.

Hundreds of years, foreign doubts divided \& denied

truth merged

molding the golden peninsula

shifting water \& land

Chenla villages into a stone metropolis,

visible from NASA above. Legacy \& some

proven legends. Stone etched conquests \& kingly

gratifications in foundation of a bygone empire.

Transcribed \& more to be

completely deciphered. Enthusiasts \& make-believe

playing gods and secular,

imagining hypotheses (only if we were there)

to mechanize each cold-stone character into events

could or not have taken place. Could they have

help mobilizing beyond their earthly

strength \& body weight into celestial realm,

rendering this race to outdo

its greatness amongst jealous gods and opportune neighbors?

\footnotetext{
(c)

SORERIIGHISRESEREED Readers are free to copy, display, and distribute this article, as long as the work is attributed to the author(s) and the Journal of Southeast Asian American Education \& Advancement, it is distributed for noncommercial purposes only, and no alteration or transformation is made in the work. More details of this Creative Commons license are available at http://creativecommons.org/licenses/by-nc-nd/3.0/. All other uses must be approved by the author(s) or JSAAEA.
} 


\section{The Mekong to Mundus Novus}

How wet starts with a drip.

From snowy Tibet Plateau through the narrow runoffs

-Through golden villages lived \& villages

on stilts drowned

$\circ$ Pushing upstream

-Coming to spawn

-As winter arrives for home in the highlands above

-Downstreaming through the land

of the one thousand water-mouths

-Slow-wetting the flatland canals

-Mobilizing the land of

gold \& the rolls of exotic silk

-Between Nokor Borei \& the port city O'Keo

$\circ$ At the

emporium of Ptolemaic golden Cattigara

-The far east most

of the Greco-Roman's ecumene

-This entrepot

-Banteay Meas

-This place means gold

-The lost sailors

-The cartographer's scribal error

-Eight and a half degrees repeated down from half earth

-The misplaced voyages

-Credited with the New World

Note: Banteay Meas appeared as Ponteamas in The Gentleman's Magazine (London, England, vol. 38, page 549)

\section{The Tonle Sap}

Like an old lover skimming over the column bones.

Like a ride on the good back of a steady beast.

Like warm thighs straddling through thin fine silk.

Like an upsurge $\&$ afterwards.

Like steep crest $\&$ down the same way

make us forget: how often we step not knowing

how we've gotten there

\& back.

Here, the continent has always reached out to the seas

$\&$ the trade cities have always migrated inwards to her womb. 


\section{Touching Water}

1

Here, where the moon touches the water

$\&$ the current

rapids like malleable

flooding cervixes

of shore roots \& eroded stone images

$\&$ ancient inscriptions proclaiming royal deeds \& offspring

pushing from shadow \& harems

onto the open vista. Image the sky after bondage

opens up for the disinherited siblings.

2

Here, where once through the old fig, the sun penetrated

deep to the precious

luminance at the bottom of clear Kulen falls.

Deflected \& projected angle: in shallow creek

water, dotting shadows \& honored locus

erected from hips of god $\&$ creation. Imagine standing

images on the horizontal plane.

3

Here, where once Khmer ancients stationed

awaiting dragon stars \& sunset

glow languished over heavy canopy

has since upturned foundation

stones \& kingdom reshuffling

between the permanent $\&$ illegitimated

usurps of half-blood kings.

4

Here, where the water is like a mirror

opening up to new air \& light is gradual

where residual settles after each entry.

5

Here, you can still see at the bottom of the falls

where all the waters pool

$\&$ the pool is a holding mirror

where the others see through dull light \&

in the light the original tribes

wheel the sun to harvest

hour then capture the old king

of rains to feed the million rice fields. 


\section{Water the Goddess}

If you are from here, you know. Each year

From June to October, the Mekong rises \& the Tonle Sap

Buckles like a goddess teased. Warm. Accepting.

Willing. Dispense. Rush. Meniscus

Curvature. Edge. Cylinder. Molecular Tension. Droplets. Solid.

Solvent legs. Incremental wonder. Gauging. Engage. Let.

Possibilities. Meander. Leisure of a backstroke. Floaty. Sky.

Leafy. Light. Random shades. Sweet \& salted.

Ocean-cradled. South China Sea.

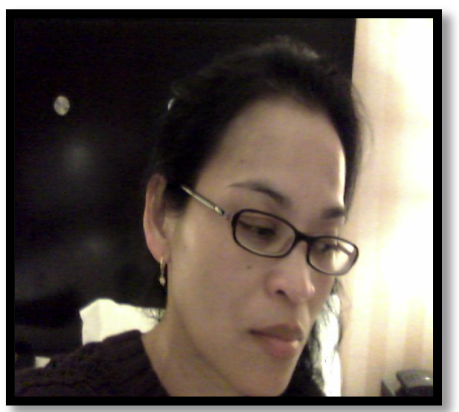

\section{About the Author}

Peauladd Huy was born in Phnom Penh. Her latest work, published by Connotation Press-An Online Artifact-was nominated for the Sundress "Best of the Net," the Dzanc "Best of the Net," and the Pushcart Prize. And with deep gratitude to Connotation Press she'll have a book, forthcoming sometime in April. 


\title{
JSA AEA Journal of Southeast Asian American Education \& Advancement
}

Volume 9 (2014)

WWW.JSAAEA.org

A peer-reviewed

scholarly journal

published by the National Association for the Education \& Advancement of Cambodian, Laotian, and Vietnamese Americans NAFEA)

\section{Editor}

Dr. Wayne E. Wright

University of Texas at San Antonio

\author{
Associate Editors \\ Dr. Chhany Sak-Humphry \\ University of Hawaii at Manoa
}

Dr. Phitsamay Sychitkokhong Uy

University of Massachusetts, Lowell

\section{Book Review Editor}

Dr. Vichet Chhuon

University of Minnesota

\section{Creative Works Editor}

Bryan Thao Worra

Lao Assistance Center

\section{Special Advisor}

Gregory Green

Curator, Echols Collection on Southeast Asia, Cornell University Library

\section{Journal Manager}

Yeng Yang

University of Texas at San Antonio

\section{Editorial Assistant}

Matthew Kraft

University of Texas at San Antonio

Comments and questions for the editorial staff may be directed to jsaaea@lists.sis.utsa.edu

\section{Editorial Review Board}

\author{
Dr. Steve Arounsack \\ California State University, Stanislaus \\ Dr. Phala Chea \\ Lowell Public Schools \\ Dr. Loan Dao \\ University of Massachusetts, Boston \\ Dr. Changming Duan \\ University of Missouri, Kansas City
}

\author{
Dr. Carl L. Bankston III \\ Tulane University \\ Dr. George Chigas \\ University of Massachusetts, Lowell \\ Dr. Hien Duc Do \\ San Jose State University \\ Dr. Sophal Ear \\ U.S. Naval Postgraduate School
}




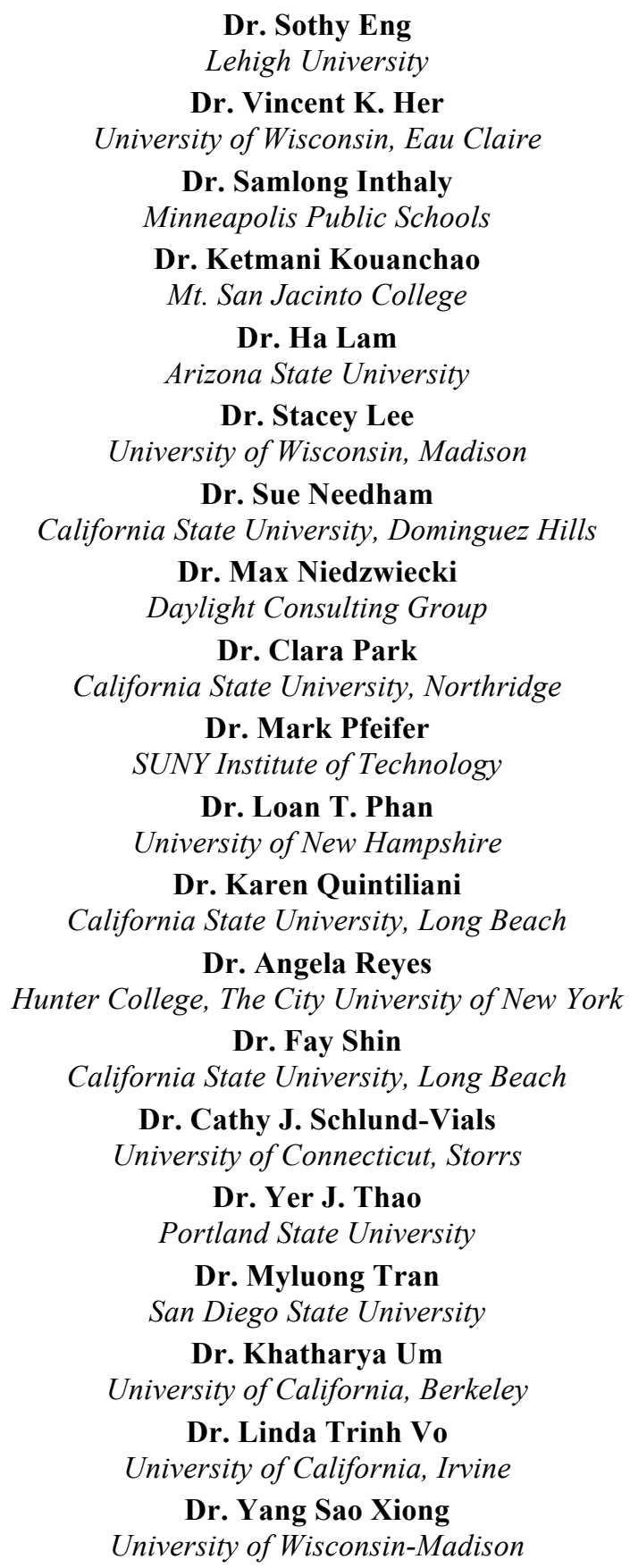

Dr. Vincent K. Her

University of Wisconsin, Eau Claire

Dr. Samlong Inthaly

Minneapolis Public Schools

Dr. Ketmani Kouanchao

Mt. San Jacinto College

Dr. Ha Lam

Arizona State University

Dr. Stacey Lee

University of Wisconsin, Madison

Dr. Sue Needham

California State University, Dominguez Hills

Dr. Max Niedzwiecki

Daylight Consulting Group

Dr. Clara Park

California State University, Northridge

Dr. Mark Pfeifer

SUNY Institute of Technology

Dr. Loan T. Phan

University of New Hampshire

Dr. Karen Quintiliani

California State University, Long Beach

Dr. Angela Reyes

Hunter College, The City University of New York

Dr. Fay Shin

California State University, Long Beach

Dr. Cathy J. Schlund-Vials

University of Connecticut, Storrs

Dr. Yer J. Thao

Portland State University

Dr. Myluong Tran

San Diego State University

Dr. Khatharya Um

University of California, Berkeley

Dr. Linda Trinh Vo

University of California, Irvine

Dr. Yang Sao Xiong

University of Wisconsin-Madison

Dr. Jeremy Hein

University of Wisconsin, Eau Claire

Dr. Nancy H. Hornberger

University of Pennsylvania

Dr. Peter Nien-Chu Kiang

University of Massachusetts, Boston

Dr. Kevin K. Kumashiro

University of Illinois, Chicago

Dr. Jonathan H. X. Lee

San Francisco State University

Dr. Monirith Ly

Texas State University-San Marcos Dr. Bic Ngo

University of Minnesota

Dr. Leakhena Nou

California State University, Long Beach

Dr. Isabelle Thuy Pelaud

San Francisco State University

Dr. Giang Pham

University of Massachusetts

Dr. Bounlieng Phommasouvanh

Minnesota Department of Education

Dr. Kalyani Rai

University of Wisconsin, Milwaukee

Dr. Soveacha Ros

Royal University of Phnom Penh

Dr. Nancy J. Smith-Hefner

Boston University

Dr. Christine Su

Ohio University

Dr. Loan Tran

University of California, Riverside

Dr. Tinou Tran

Alief Independent School District

Dr. Silvy Un

Frost Lake Elementary School

Dr. Terrence G. Wiley

Center for Applied Linguistics

Dr. Zha Blong Xiong

University of Minnesota

Dr. Kou Yang

California State University, Stanislaus

\section{Doctoral Student Editorial Review Board}

Sovicheth Boun

University of Texas at San Antonio

Keo Chea-Young

University of Pennsylvania

Dung Mao

University of Minnesota
Virak Chan

University of Texas at San Antonio

Annie BichLoan Duong

San Joaquin County Office of Education

Peter Tan Keo

Columbia University

Journal of Southeast Asian American Education \& Advancement, Vol. 9 (2014) 
Huy: Selected Poems: Folklore \& legend: Kaundinya \& Soma; The Mekong t

Peauladd Huy_-Selected Poems

Ravy Lao

University of California, Santa Barbara

Thien-Huong Ninh University of Southern California

Malaphone Phommasa

University of California, Santa Barbara

Alisia Tran

University of Minnesota

Anna H. Yang

University of Georgia
Minh Mai

University of Wisconsin-Madison

Hoa Nha Nguyen

Boston College

Vanna Som

Harvard University

Krissyvan Truong

Claremont Graduate University

Lesley Yang

University of Minnesota 